\title{
Occurrence and Distribution of the Genus Jania J. V. Lamouroux (Corallinales, Rhodophyta) in the Pacific Coast of Baja California and Gulf of California, Mexico
}

\author{
Luz Elena Mateo-Cid ${ }^{1}$, A. Catalina Mendoza-González ${ }^{1}$, Luis E. Aguilar-Rosas ${ }^{2}$, Raúl Aguilar-Rosas ${ }^{3}$ \\ ${ }^{1}$ Instituto Politécnico Nacional, Escuela Nacional de Ciencias Biológicas, Departamento de Botánica, Ciudad de México, México; \\ ${ }^{2}$ Instituto de Investigaciones Oceanológicas, Universidad Autónoma de Baja California, Ensenada, Baja California, México; \\ ${ }^{3}$ Facultad de Ciencias Marinas, Universidad Autónoma de Baja California, Ensenada, Baja California, México. \\ Email:1mateoc@ipn.mx
}

Received October $16^{\text {th }}, 2013$; revised November $17^{\text {th }}, 2013$; accepted November $28^{\text {th }}, 2013$

Copyright (C) 2013 Luz Elena Mateo-Cid et al. This is an open access article distributed under the Creative Commons Attribution License, which permits unrestricted use, distribution, and reproduction in any medium, provided the original work is properly cited.

\begin{abstract}
This paper provides a description of the articulated species of the Tribe Janieae (Corallinales, Rhodophyta) in the Pacific coast of Baja California and Gulf of California, Mexico. This taxonomic report is based on newly collected data in the study area and material currently housed at several herbaria. As a result of the present study, the record of the tribe Janieae is represented at the Pacific coast of Mexico for one genus: Jania J. V. Lamouroux with nine species. Morphological, reproductive and anatomical descriptions are provided in detail. In addition, keys for determination are included, as well as habitat, nomenclature, comparisons with other species and information on distribution. Instead of eleven species of Jania currently recorded for the study area, we recognize only nine. Jania verrucosa is restricted to the occidental coast from the Peninsula of Baja California. The remainder of the species commonly occurs in the Gulf of California and the Pacific coast of Baja California's Peninsula. On the other hand, the gametangial thalli of J. adhaerens and tetrasporangial conceptacle in J. longiarthra are reported for the first time in Mexico.
\end{abstract}

Keywords: Janieae; Morphology; Distribution; Pacific; Mexico

\section{Introduction}

All members of the subfamily Corallinoideae (J. E. Areschoug) Foslie are constructed of uncalcified genicula and calcified intergenicula and form branched fronds. The Tribe Corallineae J. E. Areschoug is characterized by genicula consisting of a single uncorticated and uncalcified tier of medullar cells and lateral cellular fusion. The genera of the Corallinoideae are referred to two tribes: the Corallineae and the Janieae, which are delimited on the basis of morphological and reproductive features $[1,2]$. The Janieae is distinguished from the Corallineae by reproductive characteristics, such as thick, compact carposporophytic fusion cells bearing marginal carposporangial filaments, male conceptacles with narrow chambers and short canals, and a comparatively small number of sporangia in each tetrasporangial conceptacle [3]. The tribe Janieae includes one genus: Jania J. V. Lamouroux. The genus Jania is an important component of the marine benthic flora in the Gulf of California. How- ever, in spite of their abundance, representatives of this genus have received little attention. The aim of this paper is to provide morphological, anatomical and reproductive accounts of this genus. Distinctive field characters as well as pertinent photographs are provided for each species.

\section{Materials and Methods}

Specimens of Jania were borrowed from ENCB (National School of Biological Sciences) of the Department of Botany, National School at Biological Sciences, Mexico, D. F.); CMMEX (School of Marine Sciences) of the Faculty of Marine Sciences, University of Baja California, Ensenada, Baja California); UC (University of California) University and Jepson Herbaria of the University of California at Berkeley and LAM (Natural History Museum of Los Angeles, California), transferred recently to UC [4], these samples were collected for different people from 1940 to 2001. Also, specimens of Jania was found in 
samples of general collections collected by reef-walking or snorkeling at Loreto, Bahia Agua Verde and La Paz. Samples were preserved in 5\% formalin/seawater. Preserved specimens were decalcified with $0.6 \mathrm{M} \mathrm{HNO}_{3}$. Small segments were stained with aniline blue and hematoxilin-eosine for anatomical observations and measurements.

The classification system of Abbott and Hollenberg [5] and Guiry and Guiry [6], are used throughout this paper. In cell measurements length denotes the distance between primary pit connections whereas diameter denotes the maximum width of the cell lumen at right angles to this. Conceptacle measurements follow the system of Johansen [7], Adey and Adey [8]. Descriptive terminalogy follows Johansen and Silva [1] and Abbott and Hollenberg [5]. Pertinent remarks about the morphology, detailed descriptive accounts, and specimens examined are provided for each species. In this study we made observations on a total of 80 specimens are housed at herbaria ENCB and CMMEX. Description of the vegetative, reproductive characters and information related to the habitat, the geographic distribution and examined specimens are included for each species.

\section{Results}

Nine species representing genus Jania were found during the present study.

\section{1) Jania J. V. Lamouroux 1812 [9]}

Calcified articulated algae of erect fronds that are primarily dichotomously branched, attached by minute to small crustose holdfast and stolon-like holdfasts. Intergenicula are cylindrical, subcylindrical or compressed, and smooth, winged or lobed. The intergenicula is usually considerably longer than broad, and composed of arching tiers of medullary cell, an outer cortex of pigmented cells, and external single-layer of epithallial cells. Medullary cells in tiers that are all the same height. Cells are with pit-connections. Trichocytes present, but not always evident. Genicula (joints) uncalcified, and consist of a single tier of long, straight cells (sometimes partially covered by overlapping calcification of intergenicula). Sporangial conceptacles contain up to $12(-15)$ tetrasporangia or bisporangia. Conceptacles are solitary and terminals with an apical pore, sometimes the conceptacles give rise to new branches, so they are called antenniferous. Carposporangial conceptacles with narrow (to 35 $\mu \mathrm{m}$ ), wide (to $130 \mu \mathrm{m}$ ) fusion cells. Spermatangial conceptacles long and narrow, lanceolate; spermatangia along inner walls of chamber.

Key to the species:

1a) Thalli epiphytic, segments markedly compressed throughout $J$. tenellavar. zacae

1b) Thalli saxicolous or epiphytic, segments normally all cylindrical, rarely compressed below

2a) Thallus with common alternate or opposite pinnate branches, in addition to the major branching dichotomous $J$. subpinnata

2b) Thallus strictly dichotomously branched

3a) Thalli decussate-dichotomously branched; branch wide angles wide, mostly greater than $45^{\circ}$, branch intergenicula $50-100 \mu \mathrm{m}$ in diameter and $400-800 \mu \mathrm{m}$ in length $J$. capillacea

3b) Thalli dichotomously branched thought branch anngles narrow, usually less than, but up to $45^{\circ}$, branch intergenicula, mostly $100-400 \mu \mathrm{m}$ in diameter

4a) Segments mostly $300-500 \mu \mathrm{m}$ in diameter J. verrucosa

4b) Segments mostly $100-200 \mu \mathrm{m}$ in diameter

5a) Segments $120-150(-210) \mu \mathrm{m}$ in diameter; very long, $6-11$ times longer than wide, $700-1200 \mu \mathrm{m}$ in length $J$. longiarthra

5b) Segments $120-200 \mu \mathrm{m}$ in diameter; mostly 2.0 5.0 times longer than wide

6a) Segments $120-200 \mu \mathrm{m}$ in diameter; tetrasporangial conceptacles seriate $J$. pacifica

6b) Segments $120-200 \mu \mathrm{m}$ in diameter; tetrasporangial conceptacles all terminal

7a) Branch angles mostly about $30^{\circ}$; branch intergenicula $120-150 \mu \mathrm{m}$ in diameter; 2 - 5 times longer than wide, (240-) $300-750 \mu \mathrm{m}$ in length $J$. adhaerens

$7 b)$ Branch angles rather narrow, mostly $45^{\circ}$ or less; segments $120-120 \mu \mathrm{m}$ in diameter; mostly $2.0-5.0$ times longer than wide

8a) Segments 120 - $200 \mu \mathrm{m}$ in diameter; and 150 - 600 $\mu \mathrm{m}$ in length; tetrasporangial conceptacles terminal $\mathrm{J}$. tenella

8b) Segments (110) 120 - 160 (170) $\mu \mathrm{m}$ in diameter and $400-580(640) \mu \mathrm{m}$ in length; with terminals bearing ungulate apices, flattened, tetrasporangial conceptacles axial J. ungulata f. brevior

2) Jania adhaerens J. V. Lamouroux, 1816:270 [10]

Type locality: "Méditerranée?" (Lamouroux 1816:270 [10]).

Morphology: Small calcified articulated algae; epiphytic, or on hard surfaces, forming dichotomously branched brittle turfs, usually less than $2 \mathrm{~cm}$ tall (Figure 1(a)); attached by a crustose base, and secondarily by creeping, rhizomatous basal segments with lateral discoid holdfasts. Branch apices generally finely modified angles, more often than not less than $30^{\circ}$. Axes are dichotomously branched, mostly in one plane, intergenicula (segments) heavily calcified, cylindrical, and sometimes slightly flattened at branch dichotomies; mostly $120-200 \mu \mathrm{m}$ in diameter and 300 - 900 in length (Figure 1(b)).

Anatomy: In longitudinal section cells of the medulla 7 - $11 \mu \mathrm{m}$ breadth and $50-90 \mu \mathrm{m}$ length, cortical region 
composed by 2 - 3 layers of cells, these of $6-8 \mu \mathrm{m}$ breadth and 9 - $10 \mu \mathrm{m}$ length. Genicula (85) 105 - 125 (140) $\mu \mathrm{m}$ breadth by (220) 240 - 312 (330) $\mu \mathrm{m}$ length.

Reproductive structures: Tetrasporangial conceptacles vase-shaped, surmounted with swollen branches (Figure 1(c)), within chambers that are $150-200 \mu \mathrm{m}$ in diameter and $250-300 \mu \mathrm{m}$ high (Figure 1(d)). Tetrasporangia are zonately divided, 120 - $130 \mu \mathrm{m}$ length and $40-45 \mu \mathrm{m}$ breadth. Male chambers $120-140 \mu \mathrm{m}$ in diameter (Figure 1(e)).

Habitat: Epilithic and in tide pools; intertidal to shallow subtidal.

Distribution: Eastern Pacific: Southern California to Todos Santos, Baja California Sur; Isla Guadalupe; Sinaloa to Colima; Hawaiian Islands; Ecuador. Western Pacific: China; Japan; Korea.

Specimens examined:Baja California (Gulf): Playa Santa Teresa, 21.X.1995, A. C. Mendoza-González and
L. E. Mateo-Cid (ENCB 12052) (Aguilar-Rosas et al. 2000:131 [11]); Puertecitos, 4.II.1996, A. C. Mendoza González and L. E. Mateo Cid (ENCB 12054) (AguilarRosas et al. 2000:131 [11]); Isla Ángel de la Guarda, E. Y. Dawson, 4.II.1940 (UC 940249). Baja California Sur (Gulf): Bahía Concepción (Las Palmas and Punta Guadalupe), 17.I.1990, L. E. Mateo-Cid and M. Aguirre (ENCB 12062); (El Coyote), 27.III.1949, E. Y. Dawson (LAM 54845 and US 0000456) (Huerta-Múzquiz and MendozaGonzález 1985: 49 [12] Mateo-Cid et al. 1993: 46 [13]); Punta Arena (Mateo-Cid et al. 2000:64 [14]); Arrecife de Cabo Pulmo (Anaya-Reyna and Riosmena-Rodríguez, 1996:863 [15].; Mateo-Cid et al. 2000:64 [14]). Sonora: Sinaloa: Mazatlán (Mendoza-González et al. 1994:106 [16]).

Remarks. Jania adhaerens is widely distributed in the Gulf of California, and has the widest distribution of the species of Jania located in this study. Yendo (1902) [17] noted that the original description of Jania adhaerens $\mathrm{J}$. V.
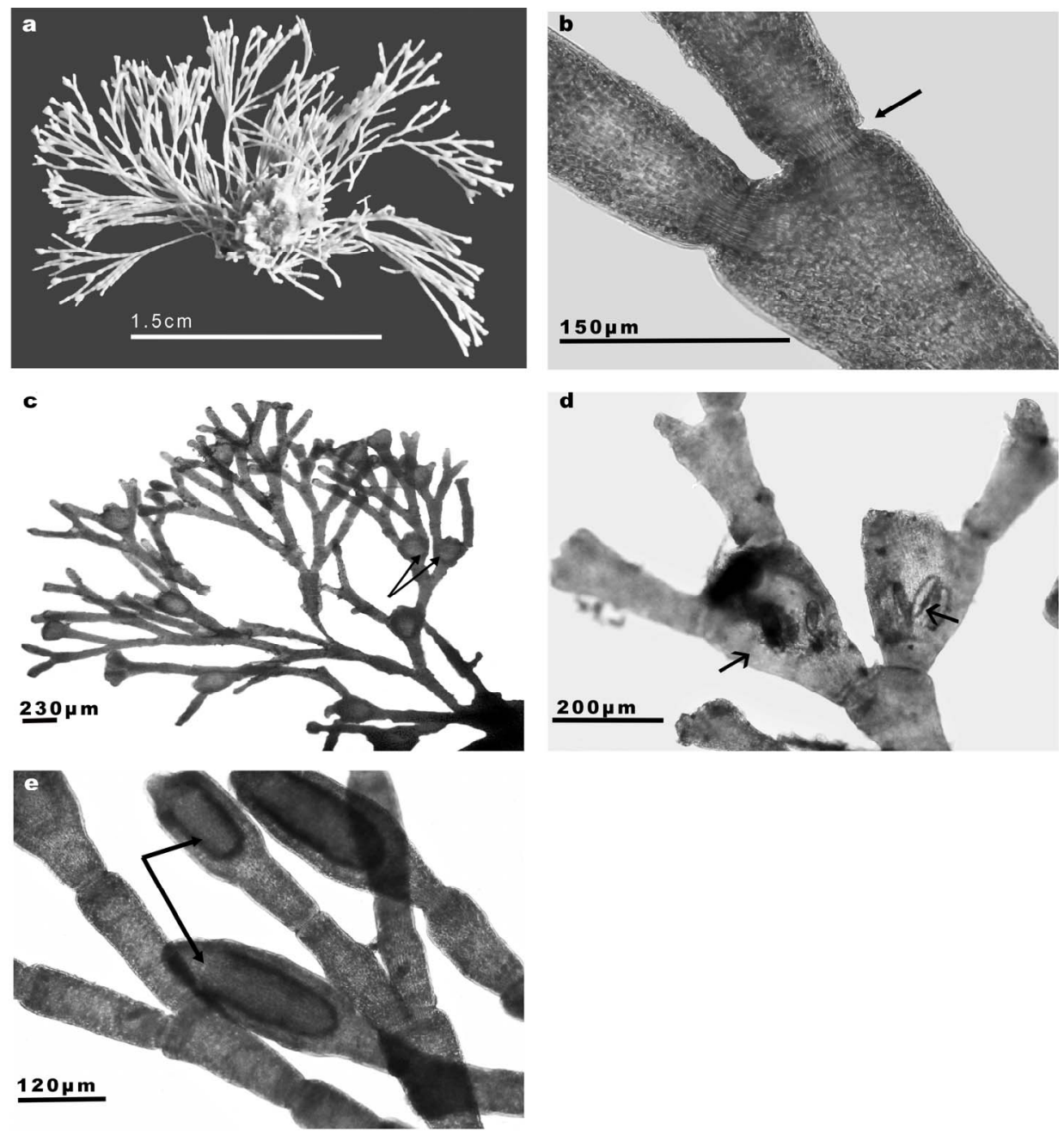

Figure 1. Jania adhaerens, (a) Habit for specimen of Puerto Penasco, Sonora. ENCB 3002; (b) Superficial view of intergeniculum and geniculum; Arrow point to geniculum; (c) Plant bearing tetrasporangial conceptacles (arrow); (d) A conceptacle filled with tetrasporangia; (e) A spermatangial conceptacle, arrow points the chamber. 
Lamouroux (1816) [10] could also apply to his J. decussato-dichotoma Yendo (1905) [18] as well.

3) Jania capillacea Harvey 1853:84 [19]

Type locality: Bahia Honda Key (Bahia Honda State Park), Florida Keys, Florida.

Morphology: Thalli minute tufts, $1.0-1.3 \mathrm{~cm}$ tall (Figure 2(a)); branching dichotomously or sometimes more or less decussate (Figure 2(b)); branch angles very wide, $60^{\circ}-90^{\circ}$; attached by a disc. Intergenicula (segments) cylindrical, $80-90 \mu \mathrm{m}$ in diameter, ultimate branches usually $50-60 \mu \mathrm{m}$ in diameter and $400-800$ $\mu \mathrm{m}$ in length (Figure 2(c)).

Anatomy: In longitudinal section cells of the medulla 7 - $9 \mu \mathrm{m}$ breadth and 25 - $50 \mu \mathrm{m}$ length, cortical region composed by $1-2$ layers of cells, these of $6-9 \mu \mathrm{m}$ breadth and $7-9 \mu \mathrm{m}$ length. Genicula $50-70 \mu \mathrm{m}$ breadth and $50-85 \mu \mathrm{m}$ length.

Reproductive structures: Tetrasporangial conceptacles, ovoid-shaped, on swollen tips of branches and occur terminally between 2 long antenna-like branches (Figure 2(d)), about $300 \mu \mathrm{m}$ wide, chambers measure 200 - 250 $\mu \mathrm{m}$ in diameter by $350-380 \mu \mathrm{m}$ length. Tetrasporangia are zonately divided, $140-150 \mu \mathrm{m}$ length and $40-45$ $\mu \mathrm{m}$ breadth (Figure 2(e)). Gametangial thallus not found.

Habitat: usually growing among other turf-algae, sometimes on rocks or epizoic on sponges; intertidal.

Distribution: Gulf of California: Puerto Peñasco; Isla Ángel de la Guarda to Cabo San Lucas. Eastern Pacific: Isla Guadalupe; Isla Cedros; Isla Socorro (Islas Revillagedo); Isla Clipperton; Baja California to Guerrero; Ecuador; Galápagos Islands.

Specimens examined: Baja California (Gulf): Punta Bufeo (Littler and Littler, 1981:151 [20]). Baja California Sur (Pacific): Laguna de San Ignacio, 09.XI.1992, RNúñez López (ENCB 12086); Baja California Sur (Gulf): Bahía Concepción (Punta Arenas), 6.XII.1992, L. E.
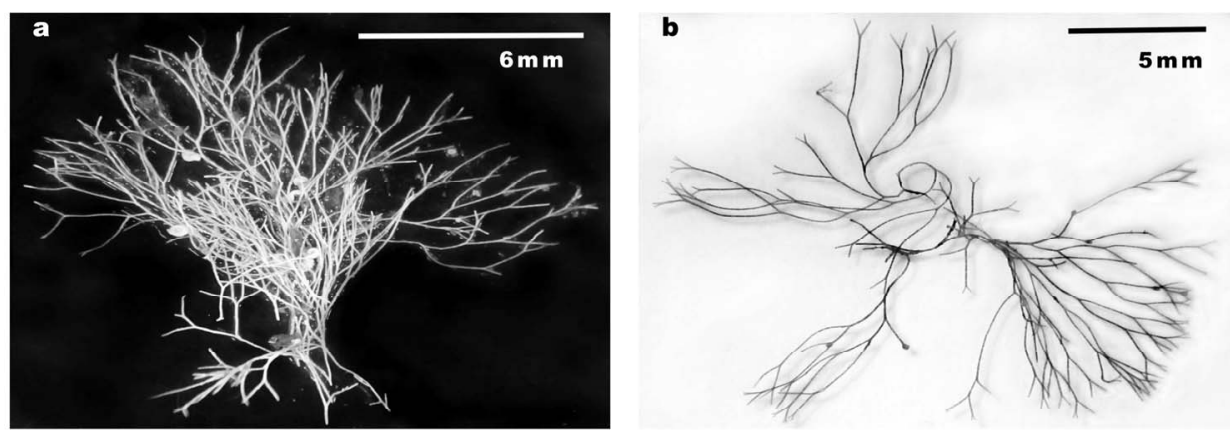

c
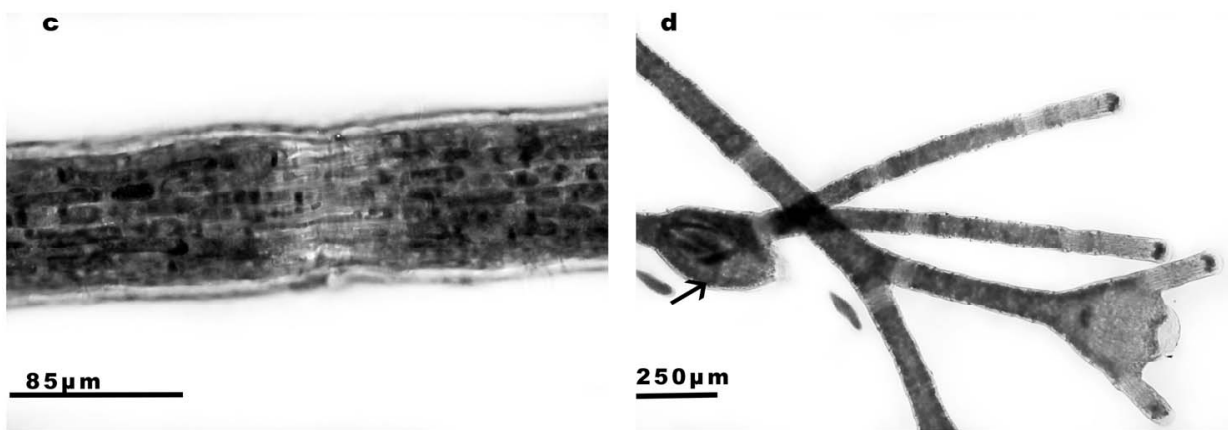

$85 \mu \mathrm{m}$

$250 \mu \mathrm{m}$

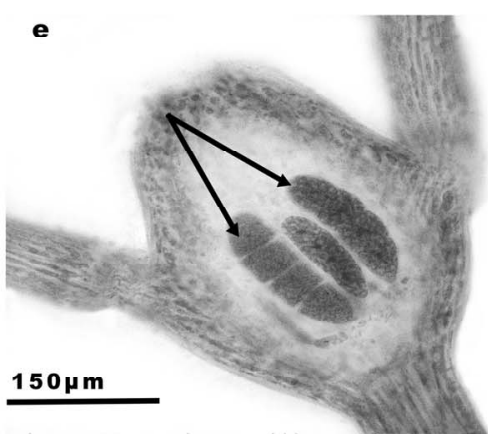

Figure 2. Jania capillacea. (a) Habit for specimen of Bahia de la Paz, BCS. ENCB SN; (b) Habit of a decalcified thallus; (c) Superficial view of intergeniculum and geniculum; (d) Plant bearing tetrasporangial conceptacles, arrow points the concepyacles; (e) A conceptacle filled with tetrasporangia, arrow point the tatrasporangia, noted the conceptacle' shaped. 
Mateo-Cid (ENCB 12087); Puerto Escondido, 11.IV. 1958, E. Y. Dawson (LAM 52689) (Dawson, 1959:7, 20, 22 [21]); Isla Partida (Dawson, 1959:4, 20, 22 [21]). Sonora: Isla Turner, 18.VII.1940, E. Y. Dawson (LAM 2693 and US 00072783). Sinaloa: Bahía Topolobampo, 15.II.1965, E. Y. Dawson (US 00004544).

Remarks. While Jania capillacea is generally recognizedas a distinct species (for example, Wynne 2005 [22]), Cribb (1983) [23] and later Price and Scott (1992) [24] have considered it to be conspecific with J. adhaerens.

4) Jania longiarthra E. Y. Dawson, 1953:119 [25]

Type Locality: Bahía San Gabriel, Isla Espíritu Santo, Baja California Sur, Gulf of California.

Morphology: Algae erect, up to $2.5 \mathrm{~cm}$ tall, forming coarse tufts; densely dichotomously branched (Figure 3(a)), sometimes rather prominently but irregularly decussate; branching at very narrow angles. Intergenicula cylindrical unconstricted (Figure 3(b)), with smooth surfaces; $200-220 \mu \mathrm{m}$ in diameter, and $720-1000 \mu \mathrm{m}$ in length, about 6 - 8 times longer than wide.

Anatomy: In longitudinal section cells of the medulla 7 - $9 \mu \mathrm{m}$ breadth and 35 - $55 \mu \mathrm{m}$ length, cortical region composed by $1-2$ layers of cells, these of $8-9 \mu \mathrm{m}$ breadth and 7 - $12 \mu \mathrm{m}$ length. Genicula $150-185 \mu \mathrm{m}$ breadth and 150 - $160 \mu \mathrm{m}$ length.

Reproductive structures: Tetrasporangial conceptacles, pyriform-shaped, terminal or subterminal, about $300 \mu \mathrm{m}$ wide, upper end with 2 - 3 long antenna-like branches, chambers $250-260 \mu \mathrm{m}$ in diameter and $390-400 \mu \mathrm{m}$ in length. Tetrasporangia are zonately divided, 160 - 190 $\mu \mathrm{m}$ length and 50 - $55 \mu \mathrm{m}$ breadth (Figure 3(c)). Gametangial thallus not found.

Habitat: Growing among other turf algae; mid to low intertidal.

Distribution. Gulf of California: Puerto Peñasco to Guaymas; Isla Carmen to Isla Espíritu Santo. Eastern Pacific: Clipperton Island (île de la Passion); Costa Rica.

Specimens examined: Baja California (Gulf): Playa Santa Teresa Aguilar-Rosas et al. 2000: [26], 21.X.1996, A. C. Mendoza-González, L. E. Mateo-Cid, L. E. Aguilar-Rosas and R. Aguilar-Rosas (ENCB 12052); Puertecitos, 3.VI.1996, A. C. Mendoza, L. E. Mateo-Cid, L. E. Aguilar-Rosas and R. Aguilar-Rosas (ENCB 12053).

Baja California Sur (Gulf): Isla Monserrat (Dawson, 1959:22 [21]); Bahía Agua Verde (Dawson, 1959:22 [21]); Isla San Diego (Dawson, 1959:22 [21]); Isla San Francisco (Dawson, 1959:8, 22 [21]); Bahía San Gabriel (Dawson, 1953:119 [21]); Puerto Balandra (Dawson, 1959:8, 22 [21]); Calerita (Bahía de La Paz, 24.IV.1994,

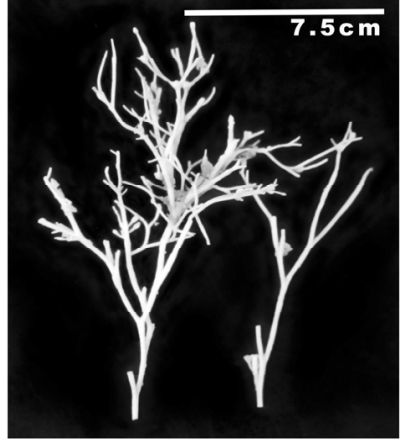

(a)

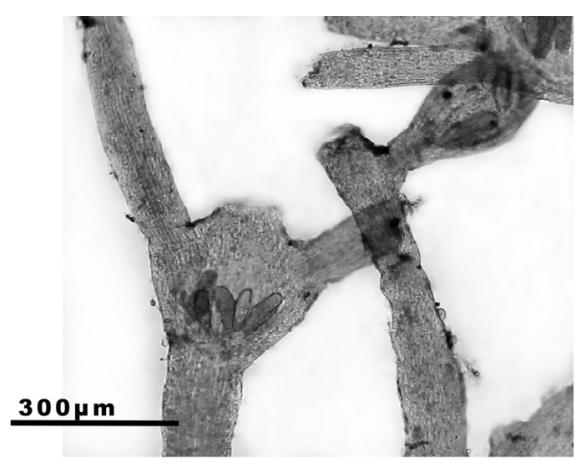

(c)

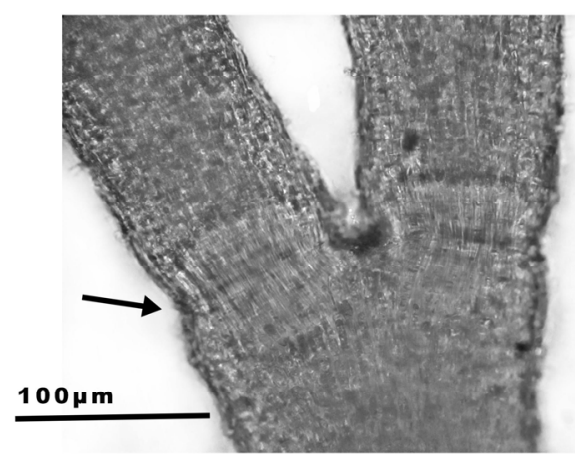

(b)

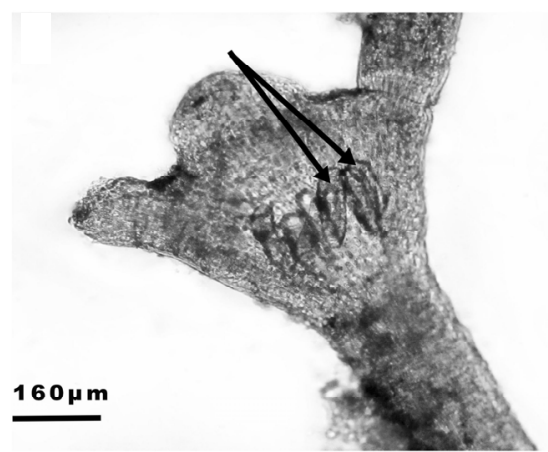

(d)

Figure 3. Jania longiarthra. (a) Habit for specimen of El Sargento, Baja California Sur ENCB 19033; (b) Superficial view of intergeniculum and geniculum, arrow point to geniculum; (c) Plant bearing tetrasporangial conceptacles; (d) Arrow point the tatrasporangia, noted the conceptacle' shaped, arrow point the tatrasporangia. 
A. C. Mendoza-González, L. E. Mateo-Cid, L. E. Aguilar-Rosas and R. Aguilar-Rosas (ENCB 19031); El Sargento, 23.IV.1994, A. C. Mendoza, L. E. Mateo, L. E. Aguilar and R. Aguilar (ENCB 19033). Sonora: Puerto Peñasco (Punta Pelícanos), 9.III.1997, A. C. MendozaGonzález, L. E. Mateo-Cid, R. Aguilar-Rosas and L. E. Aguilar-Rosas (ENCB 15758).

Remarks. Jania longiarthra has been recorded in the southern Gulf (Dawson, 1953 [25]) and upper Gulf (Mateo-Cid et al. 2006 [26]). It differs from other species of Jania reported in the Gulf, by its very long intergenicula and narrow angles of branching (Dawson 1953 [25]).

4) Jania pacifica J. E. Areschoug, 1852:556 [27]

Type Locality: Huatulco, Oaxaca, México.

Heterotipic Synonyms

Jania mexicana W. R. Taylor 1945 [28]

Morphology: Thalli attached to barnacles or saxicolous, densely tufted, (1.5) $1.8-3.5(4.0) \mathrm{cm}$ high (Figure 4(a)), branching dense subcorymbose, intergeniculas cylindrical throughout (Figure 4(b)); segments (150) $170-220(240) \mu \mathrm{m}$ in diameter and (340) $360-600(660)$ $\mu \mathrm{m}$ long, (170) $180-190$ (200) $\mu \mathrm{m}$ in diameter and (200) 220 - 400 (420) $\mu \mathrm{m}$ long in ultimate segments above; apices obtuse-conical.

Anatomy: In longitudinal section cells of the medulla 9 - $12 \mu \mathrm{m}$ breadth and $49-110 \mu \mathrm{m}$ length, cortical region composed by 2 - 3 layers of cells, these of (4.5) 7 -
9 (10) $\mu \mathrm{m}$ breadth and 12 - $18 \mu \mathrm{m}$ length. Genicula 130 $140 \mu \mathrm{m}$ breadth and $80-90 \mu \mathrm{m}$ length.

Reproductive structures: Tetrasporangial conceptacles antenniferous, terminal or subterminal (Figure 4(c)), chambers (240) 260 - 380 (420) $\mu \mathrm{m}$ in diameter and (400) $440-560(580) \mu \mathrm{m}$ in length. Tetrasporangia are zonately divided, $140-180 \mu \mathrm{m}$ length and $50-65 \mu \mathrm{m}$ breadth. Gametangial thallus not found.

Habitat: Epilithic, occurring in shallow eulittoral pools or on rocks near low tide level and $1-3 \mathrm{~m}$ deep.

Distribution. Madagascar, Taiwan, Philippines

Specimens examined: Baja California: Desembarcadero de Miller (Dawson, 1944:228 [29], as Jania mexicana). Baja California Sur: Los Cerritos (Todos Santos), 12.XI.1988, A. C. Mendoza González and L. E. Mateo Cid (ENCB 12119). Baja California (Gulf): Isla Estanque (Dawson, 1944:277 [29], as Jania rubens). Baja California Sur (Gulf): Punta Gallito (Bahía Concepción), 18.I.1990, E. Rodríguez (ENCB 12116). Sonora: Bahía Kino, 17.II.1983, L. E. Mateo-Cid and C. Flores (ENCB 12124) (Mendoza-González and Mateo-Cid, 1986:423 [30]). Sinaloa: Mazatlán (El Camarón), 8.XII.1946, E. Y. Dawson, (LAM 49519) (De Lara-Issasi, 1991:27 [31]).

Remarks: Jania pacifica is widely distributed in the tropical Pacific coast of Mexico, is infrequent on the northwest coast of Baja California and in the Gulf of California. It could be distinguished from other species of Jania present in the Pacific coast by the width-length
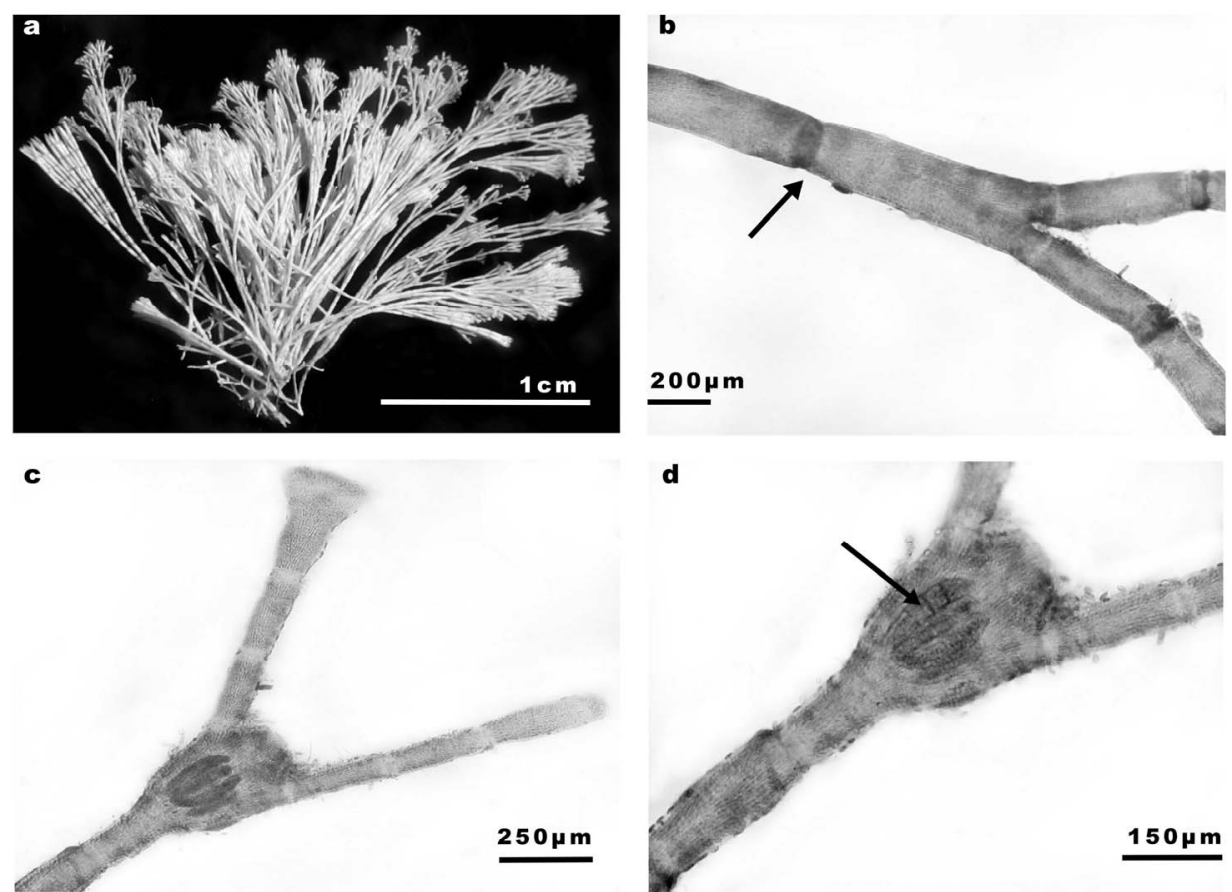

Figure 4. Jania pacifica. (a) Habit for specimen of Todos Santos, Baja California Sur ENCB 12119; (b) Superficial view of intergeniculum and geniculum, arrow points to geniculum; (c) Plant bearing tetrasporangial conceptacles; (d) A conceptacle filled with tetrasporangia, arrow point the tatrasporangia, noted the conceptacle' shaped. 
of the intergeniculas and its robust and branching habit that is denser in apical portions.

5) Jania subpinnata E. Y. Dawson 1953:115 [25]

Type locality: Bay of La Paz, Baja California Sur.

Morphology: Thalli always epiphytic, $4-6 \mathrm{~mm}$ high (Figure 5(a)), forming a densely branched, confused, matted, primary branching dichotomous, but subopposite or pinnate branching frequent and often prominent; pinnate branches arising secondarily from near the distal end of mature intergenicula, segments terete $150-170 \mu \mathrm{m}$ in diameter and 600 - $700 \mu \mathrm{m}$ long (Figure 5(b)), mostly 3 - 4 diameters long, smaller above (90) 96 - 120 (130) $\mu \mathrm{m}$ wide.

Anatomy: In longitudinal section cells of the medulla $10-12 \mu \mathrm{m}$ breadth and $18-30 \mu \mathrm{m}$ length, cortical region composed by $1-2$ layers of cells, these of $5-6 \mu \mathrm{m}$ breadth.

Reproductive structures: Tetrasporangial conceptacles urn-shaped, rostrate with antenna-like branch (Figure 5(c)), about $350 \mu \mathrm{m}$ in diameter, chambers $250-300 \mu \mathrm{m}$ in diameter and $290-300 \mu \mathrm{m}$ long, tetrasporangia are zonately divided, $110-120 \mu \mathrm{m}$ length and $55-60 \mu \mathrm{m}$ breadth (Figure 5(d)).

Habitat: Epiphytic on Dictyopteris ssp, intertidal level.

Specimens examined: Baja California Sur (Pacific): Bahía de la Paz (Dawson 1953:115 [25]). E. Y. Dawson; 10.XI.1946; Epiphityc on Digenia simplex. (HAHF 3459), Baja California (Pacific): El Sauzal, Ensenada, 12.XI.1986, Ma. E Sánchez Rodríguez (ENCB 1130A).

Remarks. As primordial characteristic for the determination of this species is the peculiar secondarily pin- nate branching distinguishes this plant readily from other species of Jania along the study area. This is the second record of J. subpinnata since it was described from Bay of La Paz.

6) Jania tenella(Kützing) Grunow, 1874:42 [32]

Type locality. Syntype localities: "in sinu neapolitano et ad oras mexicanas" (Kützing 1858:41 [33]); Gulf di Napoli, Italy (Dawson 1953 [25]) Silva et al. 1996 [34]), and Mexico (South and Skelton 2003 [35]).

Morphology: Algae forming dense tufts of congested branches, (1.0) $1.2-2.0(2.2) \mathrm{cm}$ tall, branching di- chotomous (Figure 6(a)), at narrow angles; attached by a usually inconspicuous disc. Intergenicula cylindrical (or sometimes with lower intergenicula slightly compressed), $100-120 \mu \mathrm{m}$ in diameter (Figure 6(b)), mostly $2.5-5.0$ times longer than wide, $150-600 \mu \mathrm{m}$ in length.

Anatomy: In longitudinal section cells of the medulla $7-8 \mu \mathrm{m}$ breadth and $40-60 \mu \mathrm{m}$ length, cortical region composed by $1-2$ layers of cells, these of $4-6 \mu \mathrm{m}$ breadth and $9-12 \mu \mathrm{m}$ length (Figure 6(c)). Genicula 50 - $60 \mu \mathrm{m}$ breadth and $70-90 \mu \mathrm{m}$ length.

Reproductive structures: Tetrasporangial conceptacles, urn-shaped, up to $250 \mu \mathrm{m}$ in diameter, with long extensions from prominent shoulders. Chambers measure 150 - $175 \mu \mathrm{m}$ in diameter and $300-350 \mu \mathrm{m}$ in length, tetrasporangia are zonately divided, $150-170 \mu \mathrm{m}$ length and $35-50 \mu \mathrm{m}$ breadth (Figure 6(d)). Carposporangial conceptacle, urn shaped $200-250 \mu \mathrm{m}$ Indiameter (Figure 6(e)), chambers $160-170 \mu \mathrm{m}$ in diameter and $210-230$ $\mu \mathrm{m}$ in length. Spermatangial concepttacles elongate ellipsoidal (Figure 6(f)), chamber about $110-130 \mu \mathrm{m}$ in
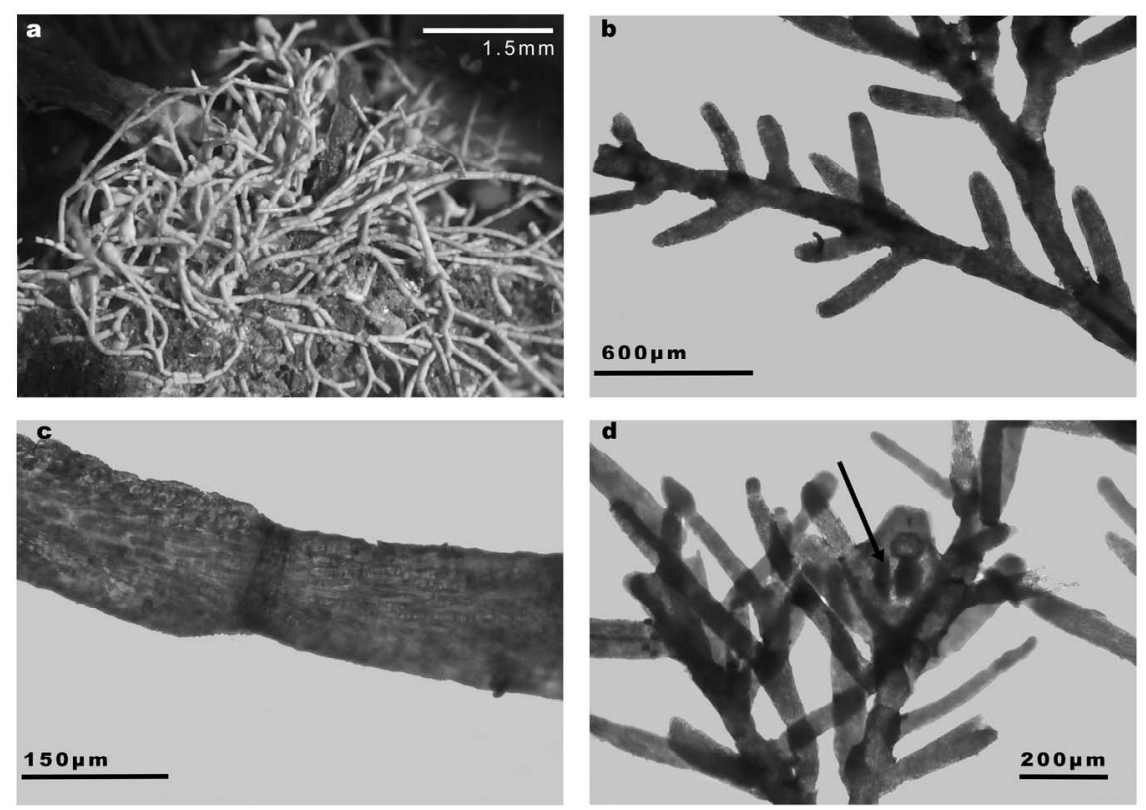

Figure 5. Jania subpinnata. (a) Habit for specimen of El Sauzal, Baja California ENCB 1130A; (b) Terminal branch with subopposite braching; (c) Superficial view of intergeniculum and geniculum; (d) Plant bearing tetrasporangial conceptacles. 

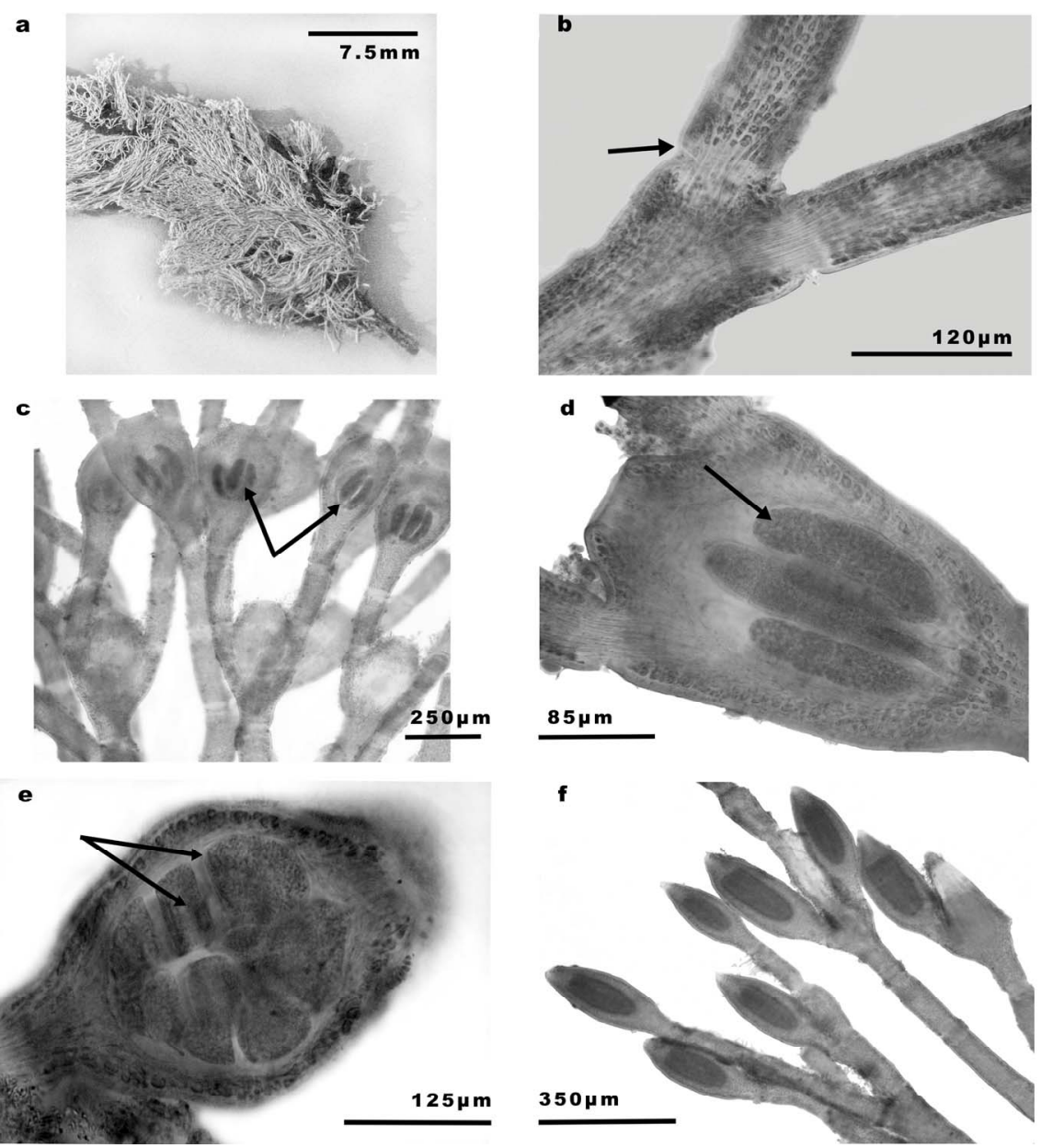

Figure 6. Jania tenella. (a) Habit for specimen of Bahia Agua Verde, BCS. ENCB 18715; (b) Superficial view of intergeniculum and geniculum. Arrow point to geniculum; (c) Plant bearing tetrasporangial conceptacles, arrow points the concepyacles; (d) A conceptacle filled with tetrasporangia, arrow point the tatrasporangia, noted the conceptacle' shaped; (e) A cystocarpic mature conceptacle, arrow points to carposporangia; (f) A spermatangial conceptacle, arrow points the chamber.

diameter and $300-350 \mu \mathrm{m}$ in length.

Habitat: Epiphytic on various algae, occasionally on rocks; mid to low intertidal.

Distribution.Gulf of California: Puerto Peñasco Punta Palmilla to Cabo Pulmo; Mazatlan. Eastern Pacific: Santa Catalina Island (California Channel Islands); southern California to Bahía Magdalena, Baja California Sur; Rocas Alijos; Sinaloa to Michoacán; Costa Rica; Chile; Rapa Nui (= Easter Island). Western Pacific: Japan.

Specimens examined: Baja California (Gulf): Playa Santa Teresa, 30.VIII.1996, A. C. Mendoza-González and L. E. Mateo-Cid (ENCB 12329); (Aguilar-Rosas et al. 2000:131 [11]); Isla Rasa, 21.XI.1964, E. Y. Dawson (US 00037336).Baja California Sur (Gulf): Isla San Ildefonso, 24.IV.1958, E. Y. Dawson, (LAM 52704); Bahía de La Paz(Calerita), 15.X.1979, G. Hernández and M. L. Chávez B. (ENCB 5273) (Huerta-Múzquiz and Mendoza-González, 1985:50 [12]); Arrecife Cabo Pulmo (Anaya-Reyna and Riosmena-Rodríguez, 1996:863 [15]); San
José del Cabo, 7.XI.1946, E.Y. Dawson (US 00004567). Sonora: Puerto Peñasco, 20.XI.1971, R. Setzer (LAM 85803).

Remarks. Jania tenella is apparently restricted to the warmer subtropical waters. We described for the first time the male and female thalli in the Gulf of California.

7) Jania tenella (Kützing) Grunow var. zacae E. Y. Dawson, 1953:121-122 [25]

Type locality.Bahía Piedra Blanca, Costa Rica.

Morphology: Thalli always epiphytic, 4 - $6 \mathrm{~mm}$ high (Figures 7(a), and (b)), forming separate and widely spaced tufts on the host, consisting of several erect, branched parts from a small disc, branching dichotomous throughout (Figure 7(c)) intergenicula compressed (60) 65 - 70 (84) $\mu \mathrm{m}$ wide and (170) 180 - 210 (220) $\mu \mathrm{m}$ long below, mostly 2 - 2.5 diameters long, smaller above (90) 96 - 120 (130) $\mu \mathrm{m}$ wide (Figure 7(d)).

Anatomy: In longitudinal section cells of the medulla $5-7 \mu \mathrm{m}$ breadth and $25-35 \mu \mathrm{m}$ length, cortical region 


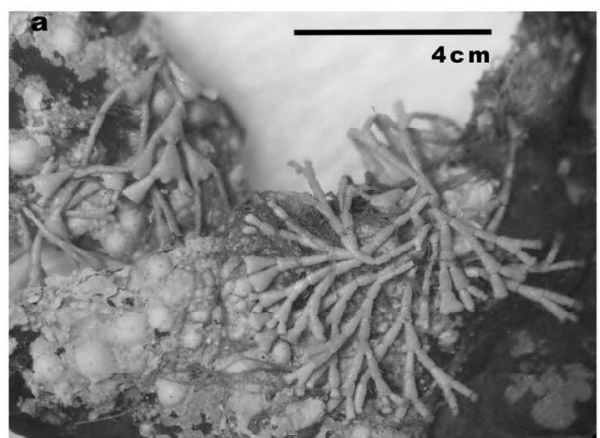

c
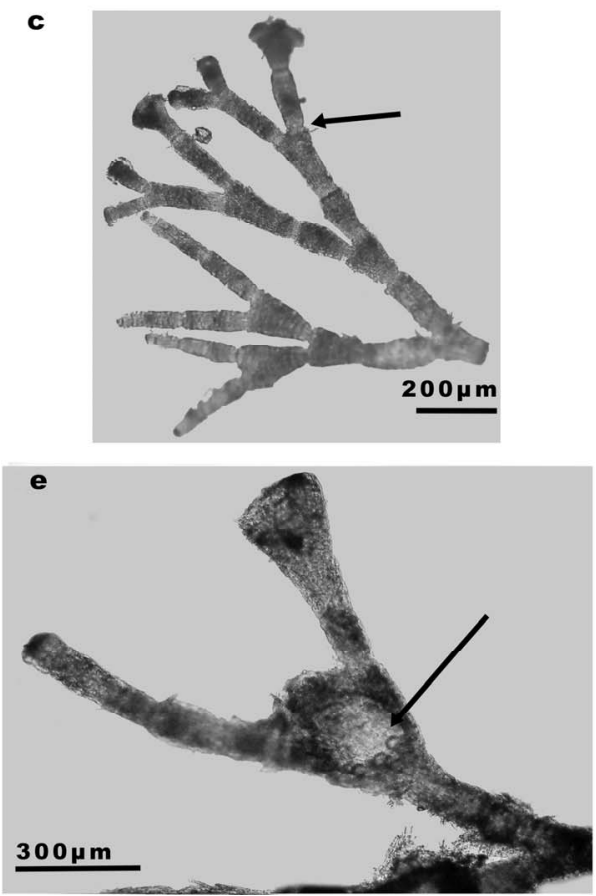
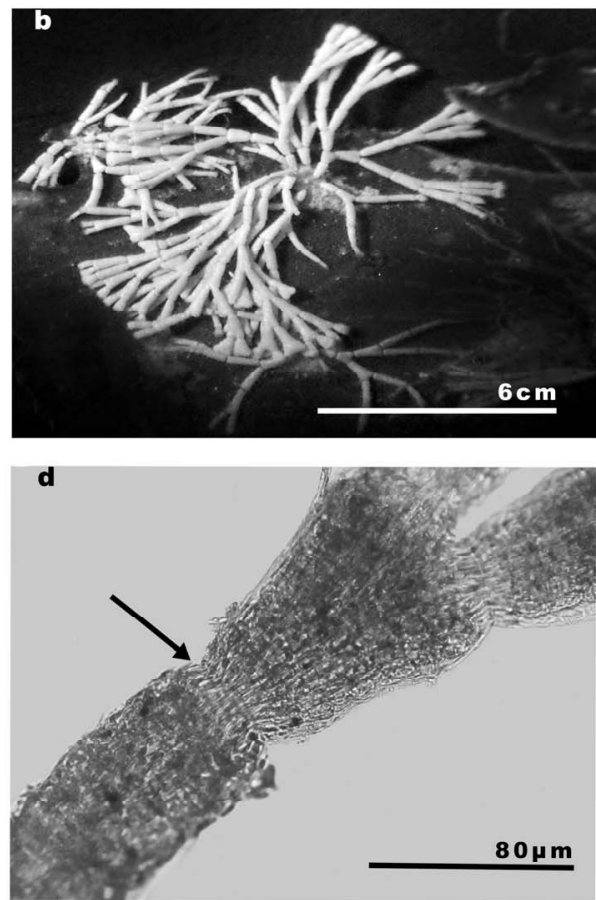

Figure 7. Jania tenella var. zacae. (a) and (b) Habit for specimen of Punta Cabeza Mechudo, Bahia de la Paz, Baja California Sur. ENCB 19343; (c) Terminal branch with subopposite braching; (d) Superficial view of intergeniculum and geniculum, arrow point to geniculum; (e) Plant bearing tetrasporangial conceptacles, noted the conceptacle' shaped.

composed by one layer of cells, these of $5-6 \mu \mathrm{m}$ breadth. Genicula (65) 70 - $80 \mu \mathrm{m}$ breadth (Figure 7(d)).

Reproductive structures: Tetrasporangial conceptacles urn-shaped, slightly compressed, about $325 \mu \mathrm{m}$ in diameter, rostrate with antenna-like branch, chambers (200) 220 - 230 (245) $\mu \mathrm{m}$ in diameter and (250) 266 - 290 (300) $\mu \mathrm{m}$ long, tetrasporangia are zonately divided, (90) 96 100 (110) $\mu \mathrm{m}$ length and (60) 62 - 65 (68) $\mu \mathrm{m}$ breadth.

Habitat: Epiphytic on Sargassum ssp, intertidal.

Distribution. Costa Rica, Philippines

Specimens examined: Baja California Sur (Pacific): Punta Malarrimo (Bahía de Sebastián Vizcaíno), (Dawson, 1953:121-122 [21]). Baja California Sur (Gulf): Isla San Ildefonso (Dawson, 1959:9, 22 [21]). (Punta Cabeza de Mechudo, Bahía de La Paz), 11.I.1988, I. Sánchez Rodríguez and Ma. C. Fajardo (ENCB 19343).

Remarks. Jania tenella var. zacae, is a rare species, perhaps due to its epiphytic habit and size go undetected or be confused with other species of Jania. This taxa could be distinguished from other species of Jania by its size and the shape of the intergeniculas.

8) Jania ungulata (Yendo) Yendo f. brevior (Yendo) Yendo: 1905:38 [18]

Corallina ungulata Yendo f. brevior Yendo 1902:27. [17]

Type locality. Province of Boshu, Chiba, Japan.

Morphology: Thalli consisted of articulate erects delicate fronds to $1.0 \mathrm{~cm}$ height (Figure 8(a)), arising from diminutive, calcified, semi-circular crustose base, branching dichotomously in a single plan. Intergenicula terete, segments (110) 120 - 160 (170) $\mu \mathrm{m}$ in diameter and 400 580 (640) $\mu \mathrm{m}$ long below, (100) 105 - $180 \mu \mathrm{m}$ in diameter and 450 - $730(800) \mu \mathrm{m}$ long in middle portions; terminal branches bearing ungulate apices (Figure 8(b)) 
180 - $260(280) \mu \mathrm{m}$ wide.

Anatomy: In longitudinal section cells of the medulla 7 - $12 \mu \mathrm{m}$ breadth and $60-85 \mu \mathrm{m}$ length, cortical region composed by $1-2$ layers of cells, these of $7-10 \mu \mathrm{m}$ breadth and $14-20 \mu \mathrm{m}$ length. Genicula (60) $70-100$ (110) $\mu \mathrm{m}$ breadth by (80) $90-130 \mu \mathrm{m}$ length.

Reproductive structures: Tetrasporangial conceptacles were terminals, antenniferous (Figure 8(c)) oval-shaped, slightly compressed, about $250 \mu \mathrm{m}$ in diameter, chambers $165-200(220) \mu \mathrm{m}$ in diameter and (220) $240-280$ (300) $\mu \mathrm{m}$ long, tetrasporangia are zonately divided (Figure 8(d)), 90 - 120 (130) $\mu \mathrm{m}$ length and (35) 40 - $60 \mu \mathrm{m}$ breadth.

Habitat: Growing on rocks, intertidal. Distribution. Kenya, India, Philippines, Australia and New Zealand Specimens examined: Baja California Sur (Pacific): Punta Conejo, 5.XII.1992, L. E. Mateo Cid and A. C. Mendoza González (ENCB 14204).

Remarks. As primordial characteristic for the determination of this species is the form of the apical intergeniculas ungulate, this feature appears to be unique to this taxon. Taylor (1945) [28] reported, as uncertain, the presence of Jania ungulata f. brevior to Ecuador. On the other hand, Moura and Yamaguishi-Tomita (1998) [36] mentioned that J. ungulata f. brevior is a typical representative of the tropical flora.

9) Jania verrucosa Lamouroux, 1816:270 [10]

Type locality. "Amérique Méridionale".

Sinónimos taxonómicos:

Jania crassa Lamouroux, 1821:23. [37]
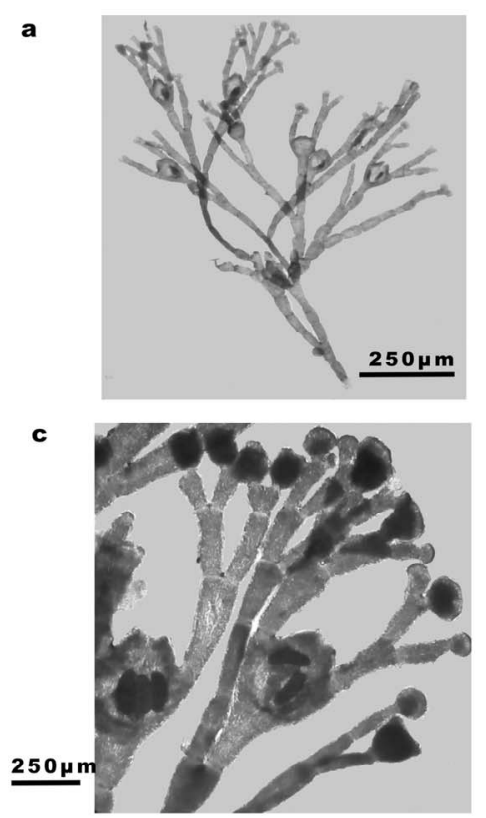

Figure 8. Jania ungulata. f. brevior. (a) Habit for specimen of Punta Conejo, Baja California Sur. ENCB 14204; (b) Superficial view of terminal urgulated apices; (c) Plant bearing tetrasporangial conceptacles, noted the conceptacle' shaped; (d) A conceptacle filled with tetrasporangia, arrow point the tatrasporangia, noted the conceptacle' shaped.

Jania natalensis Harvey, 1849 (1847-1849):107. [38]

Morphology: Thallus saxicolous, forming clumps (4) $5.0-7.5(9.0) \mathrm{cm}$ high, usually of a pink color, consisting of erect cylindrical, richly branched parts from a crustose basal stratum (Figure 9(a)), branching dichotomous throughout (Figure 9(b)), basal intergeniculas terete (Figure 9(c)), (400) 420 - 500 (520) $\mu \mathrm{m}$ in diameter and (0.4) 0.5 - 1.5 (1.7) $\mathrm{mm}$ long; the middle portion of (180) $190-200(220) \mu \mathrm{m}$ in diameter and (450) $460-530$ (700) $\mu \mathrm{m}$ length; apices obtuse-conical (170) 180 - 190 (210) $\mu \mathrm{m}$ in diameter.

Anatomy: In longitudinal section cells of the medulla (8) 9 - 12 (14) $\mu \mathrm{m}$ breadth and 91 - $105 \mu \mathrm{m}$ length, cortical region composed by $2-3$ layers of cells, these of (11) $12-14$ (15) $\mu \mathrm{m}$ breadth and (15) $16-18$ (20) $\mu \mathrm{m}$ length. Genicula 50 - $120 \mu \mathrm{m}$ breadth and (120) 130 $160(180) \mu \mathrm{m}$ length.

Reproductive structures: Tetrasporangial conceptacles not abundant, forming the terminal bulge or short-clavate terminal segments, bi or tri-antenniferous (Figure 9(d)), within chambers that are (360) $370-420(440) \mu \mathrm{m}$ in diameter and $\mu \mathrm{m}$ (360) 380 - 450 (480) $\mu \mathrm{m}$ high. Tetrasporangia are zonately divided, (105) 110 - 124 (130) $\mu \mathrm{m}$ length and (30) 35 - 40 (46) $\mu \mathrm{m}$ breadth (Figure 9(e)). Gametangial thallus not found.

Habitat: Epilithic, occurring in shallow eulittoral pools or on rocks near low tide level.

Distribution. Cape Verde Islands, California, Angola, Kenia, South Africa, China, Singapur, Hawaiian Islands, Azores, Indonesia, Brazil.
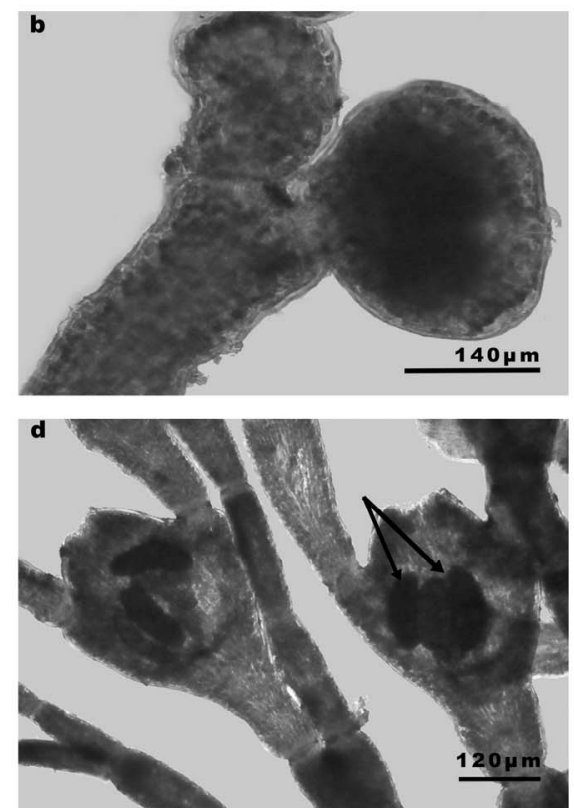


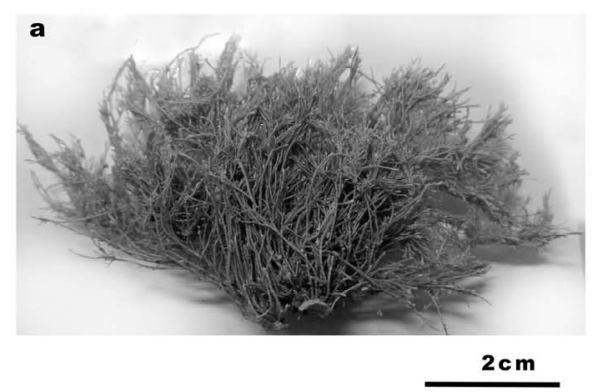

b

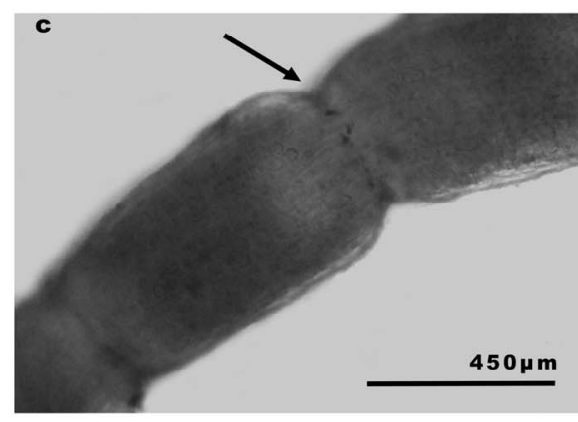

d
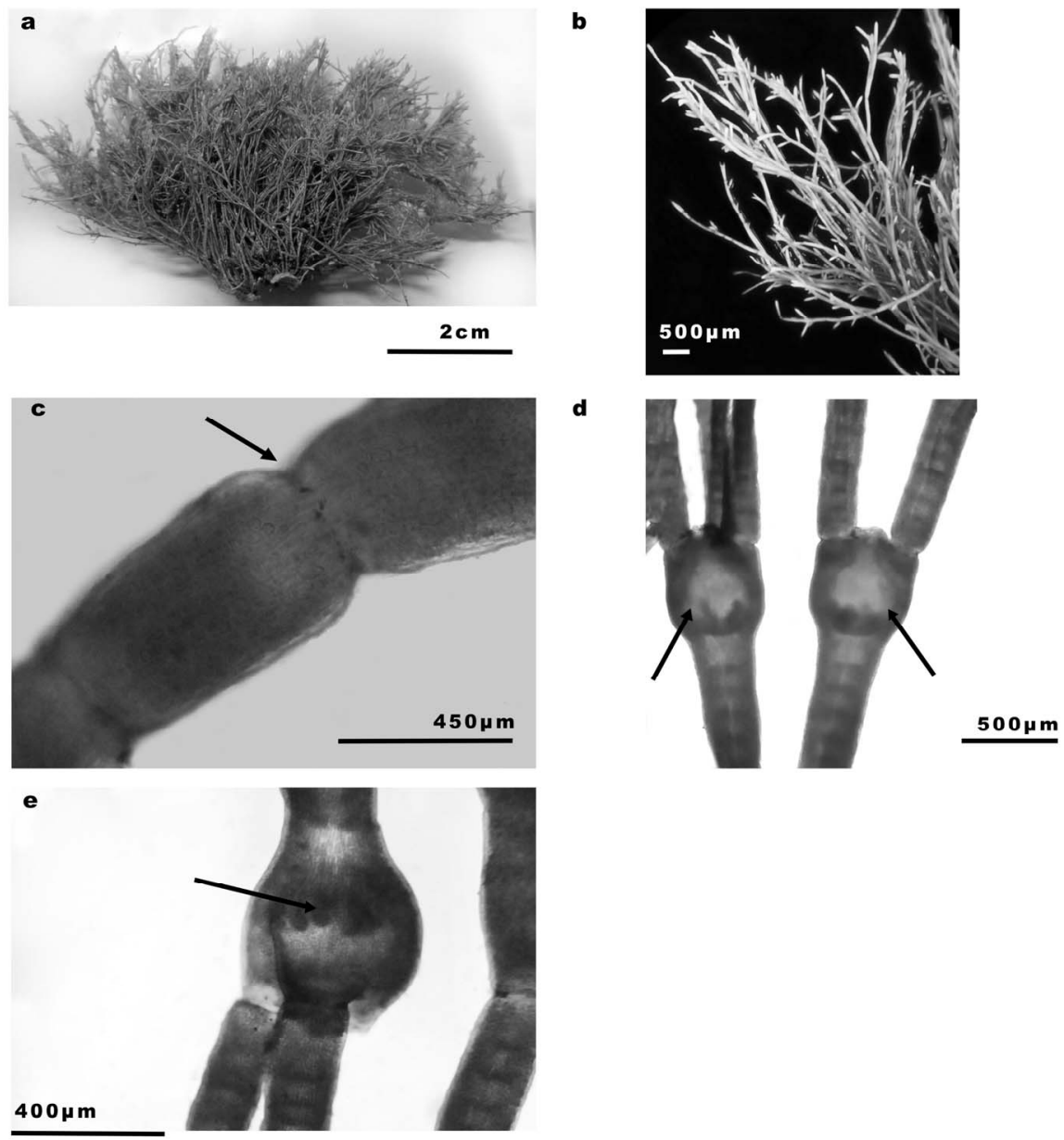

Figure 9. Jania verrucosa. (a) Habit for specimen of Rancho Packard, Ensenada, Baja California ENCB 12331; (b) Terminal branch with lateral braching; (c) Superficial view of tergeniculum and geniculum, arrow point to geniculum; (d) and (e) Plant bearing long antenniferous tetrasporangial conceptacles, arrow point the conceptacles,noted the conceptacle shaped.

Specimens examined: Baja California (Pacific): Ensenada, 2.XI.1982, A. C. Mendoza-González and C. Flores (ENCB 12127); Punta Descanso (Dawson 1949: 218 [39] as Jania mexicana; Dawson, 1953:118 [25], as Jania natalensis); Raúl's, (Pacheco-Ruíz and AguilarRosas, L. 1984:72 [40], as J. crassa); Bahía de Todos Santos (Aguilar-Rosas, L., 1981:93 [41]; Aguilar-Rosas, L. et al. 1985 [42]:125, Aguilar-Rosas, L. and PachecoRuíz, 1989:81-82 [43], as J. crassa). Baja California Sur (Pacific): Laguna Ojo de Liebre (Dawson, 1952:429, as J. natalensis); Punta Márquez (Littler and Arnold, 1982:309 [44], as J. crassa). Baja California Sur (Pacific). Bahía Tortugas, 18.XI.1986, A. C. Mendoza González and C. Flores (ENCB 12117).

Remarks. Jania verrucosa occurs only on the Pacific coast of the Baja California Peninsula and is easily distinguished by its size and robust habit as well as the relation width-length of the intergeniculas. In this study we recorded for first time the distribution of this species towards the south of the Peninsula of Baja California.

\section{Discussion}

The genus Jania is widely distributed in tropical and subtropical waters of the planet [45]. The total number of described species of this genus is controversial, are considered from 20 - 70 [46,47]. According to Johansen and Womersley (1994) [48], many species need to be reexamined due to inappropriate diagnosis or nomenclatural problems. During the analysis of articulate coralline $J a$ nia from the shores of the Gulf of California was verified the presence of four taxa. It was established that several species have problems for correct recognition. There are also other species have been recorded for the Gulf of California, but could not confirm its presence, as in the case of Jania decussata-dichotoma Yendo, two samples were reviewed, but these are very close to Jania adhaerens. In fact, Johansen (1970) [7], Yoshida (1998) [49], and Price and Scott (1992) [24] have considered J. decussato-dichotoma conspecific with J. adhaerens.

Jania huertae, was described from the northern Gulf, and is only known from the type specimen. (Chávez- 
Barrera 1972) [50]. Unfortunately, the type is lost and during this study we did not find specimens that confirm the presence of this taxon in the study area. In addition to reviewing the original description of J. huertae, it seems to be closely related to J. longiarthra, mainly in the morphology of both species. Furthermore, J. huertae was described based only on morphological characteristics and reproductive structures were not reported, by this reasons in this study we considerer J. huertae as a doubtful record, until locate the type specimen or find samples that are consistent with the characteristics of J. huertae.

\section{Conclusion}

Relationships among the species of Jania are very complex, and our morphological data indicate that the species of Jania could be delineated by the branching pattern of the main axes, intergenicular shape, and conceptacle position. However, the information provided by the analysis of vegetative and reproductive characteristics is not enough, so it requires molecular studies to achieve a more consistent classification of this genus.

\section{Acknowledgments}

Thanks to the Instituto Politécnico Nacional and the Universidad Autónoma de Baja California for the support granted to this study. Thanks to the Operation and Development Committee of Academic Activities-IPN for support to the first and second author. Carlos A. Sánchez Mendoza designed plates.

\section{REFERENCES}

[1] H. W. Johansen and P. C. Silva, "Janieae and Lithotricheae: Two New Tribes of Articulated Corallinaceae (Rhodophyta)," Phycologia, Vol. 17, No. 4, 1978, pp. 413417.

[2] D. J. Garbary and H. W. Johansen, "Scanning Electron Microscopy of Corallina and Haliptilon (Corallinaceae, Rhodophyta)," Surface Features and Their Taxonomic Implications, Vol. 18, No. 2, 1982, pp. 211-219.

[3] J. H. Kim, M. D. Guiry, J. H. Oak, D. S. Choi, S. H. Kang, H. Chung and H. G. Choi, "Phylogenetic Relationships within the Tribe Janieae (Corallinales, Rhodophyta) Based on Molecular and Morphological Data: A Reappraisal of Jania," Journal of Phycology, Vol. 43, No. 6, 2007, pp. 1310-1319.

[4] P. K. Holmgren, N. H. Holmgren and L. C. Barnett, "Index Herbariorum. Part I. The Herbaria of the World," New Handork Botanical Garden, New York, 1990, 693 p.

[5] I. A. Abbott and G. J. Hollenberg, "Marine Algae of California," Stanford University Press Stanford California, 1976, 827 p.

[6] M. D. Guiry and M. Guiry, "AlgaeBase Version 4.2," World-Wide Electronic Publication, National Universi- tand of Ireland, Galwaand, 2010.

http://www.algaebase.org

[7] H. W. Johansen, "The Diagnostic Value of Reproductive Organs in Some Genera of Articulated Coralline Red Algae," British Phycological Journal, Vol. 5, No. 1, 1970, pp. 79-86.

[8] W. H. Adey and P. J. Adey, "Studies of the Biosystematics and Ecology of the Epilithic Crustose Corallinaceae of the British Isles," British Phycological Journal, Vol. 8, No. 4, 1973, pp. 343-407.

[9] J. V. F. Lamouroux, "Extrait d'um Mémoire sur la Classification des Polypiers Coralligenes non Entierement Pierreux," Nouvaux Bulletin des Sciences, Publiqué par la Societé Philomatique de Paris, Vol. 3, 1812, pp. 181-188.

[10] J. V. F. Lamouroux, "Histoire des Polypiers Coralligénes Flexibles, Vulgairement Nommés Zoophytes. Caen, France," 1816, Ixxxiv + 559 (560 = errata) pp., xix pls., (1) folded Table.

[11] L. E. Aguilar-Rosas, R. Aguilar-Rosas, A. C. MendozaGonzález and L. E. Mateo-Cid, "Marine Algae from the Northeast Coast of Baja California, México," Botanica Marina, Vol. 43, No. 2, 2000, pp. 127-140. http://dx.doi.org/10.1515/BOT.2000.013

[12] L. Huerta-Múzquiz and A. C. Mendoza-González, "Algas marinas de la parte sur de la Bahía de La Paz, B.C.S.," Phytologia, Vol. 59, No. 1, 1985, pp. 35-37.

[13] L. E., Mateo-Cid, I. Sánchez-Rodríguez, E. RodríguezMontesinos and M. M. Casas, "Estudio Florístico de las Algas Marinas Bentónicas de Bahía Concepción, B.C.S.," Ciencias Marinas, Vol. 19, No. 1, 1993, pp. 41-60.

[14] L. E. Mateo-Cid, A. C Mendoza-González, C. GaliciaGarcía and L. Huerta-Múzquiz, "Contribución al Estudio de las Algas Marinas Bentónicas de Punta Arena y Cabo Pulmo, Baja California Sur, México," Acta Botánica Mexicana, No. 52, 2000, pp. 55-73.

[15] R. G. Anaya and R. Riosmena-Rodríguez, "Macroalgas del Arrecife Coralino de Cabo Pulmo-Los Frailes, B.C.S., México," Revista Biología Tropical, Vol. 44, No. 2, 1996, pp. 903-906.

[16] A. C. Mendoza-González, L. E. Mateo-Cid and L. Huerta Múzquiz, “Algas Marinas Bentónicas de Mazatlán, Sinaloa, México,” Acta Botánica Mexicana, No. 27, 1994, pp. 99-115.

[17] K. Yendo, "Coralline Verae Japonica," Journal of the College of Science, Imperial University of Tokyo, Vol. 12, No. 2, 1902, pp. 1-36.

[18] K. Yendo, "A Revised List of Coralline," Journal of the College of Science, Imperial University of Tokyo, Vol. 20, No. 2, 1905, pp. 1-46.

[19] W. H. Harvey, "Nereis Boreali-Americana Part II. Rhodospermeae," Smithsonian Contributions to Knowledge, Vol. 5, No. 5, 1853, 258 p.

[20] M. M. Littler and D. S. Littler, "Intertidal Macrophyte Communities from Pacific California and the Upper Gulf of California: Relatively Constant vs. Environmentally Fluctuating Systems," Marine Ecology Progress Series, No. 4, 1981, pp. 145-158. 
[21] E. Y. Dawson, "Marine Algae from the 1958 Cruise of the Stella Polaris in the Gulf of California," Los Angeles County Museum Contributions in Science, Vol. 27, 1959, $39 \mathrm{p}$

[22] M. J. Wynne, "A Check-List of Benthic Marine Algae of the Tropical and Subtropical Western Atlantic: Second Revision," Beihefte zur Nova Hedwigia, Vol. 129, 2005, pp. 1-152.

[23] A. B. Cribb, "Marine Algae of the Southern Great Barrier Reef. Part I Rhodophyta," Australian Coral Reef Society Handbook, Vol. 2, No. 173, 1983, p. 71.

[24] R. Price and F. J. Scott, "The Turf Algal Flora of the Great Barrier Reef. Part I. Rhodophyta,” Botany Department, James Cook University, Townsville, 1992, pp. xii + 266, 81 Figs.

[25] E. Y. Dawson, "Marine Red Algae of Pacific Mexico I. Bangiales to Corallinoideae," Allan Hancock Pacific EXpeditions, Vol. 17, No. 1, 1953, pp. 1-239.

[26] L. E, Mateo-Cid, A. C. Mendoza-González, R. AguilarRosas and L. E. Aguilar-Rosas, "Algas Marinas Bentónicas de Puerto Peñasco, Sonora, México," Hidrobiológica, Vol. 16, No. 1, 2006, pp. 45-65.

[27] J. E. Areschough, “Ordo XII. Corallineae,” In: J. G. Agardh, Ed., Species Genera et Ordines Algarum Volumen Secundum: Algas Florideas Complectens (Lund), 1852, pp. 506-576.

[28] W. R. Taylor, "Pacific Marine Algae of the Allan Hancock Expeditions to the Galapagos Islands," Allan Hancock Pacific Expeditions, Vol. 12, No. 1, 1945, pp. 1-528.

[29] E. Y. Dawson, "The Marine Algae of the Gulf of California," Allan Hancock Pacific Expeditions, Vol. 3, No. 10, 1944, pp. 1-450.

[30] A. C. Mendoza-González and L. E. Mateo-Cid, Flora Marina Bentónica de la Costa Noreste del Estado de Sonora, México," Phytología, Vol. 60, No. 6, 1986, pp. 414-427.

[31] G. De Lara-Isassi and S. Álvarez-Hernández, "Propiedades Antibióticas de Algunas Especies de Algas Marinas Bénticas," Hidrobiológica, Vol. 1, No. 2, 1991, pp. 2128.

[32] A. Grunow, "Algen der Fidschi, Tonga-und Samoa-Inseln, Gesammelt von Dr. E. Graeffe," Journal des Museums Godeffroy (Hamburg), Vol. 3, 1874, pp. 23-50.

[33] F. T. Kützing, “Tabulae Phycologicae," Vol. 8, 1858, Nordhausen. II +48 pp. 100 pls.

[34] P. C. Silva, P. W. Basson and R. L. Moe, "Catalogue of the Benthic Marine Algae of the Indian Ocean," University California Publications of Botany, Vol. 79, No. 1, 1996, xiv +1259 pp.

[35] G. R. South and P. K. Skelton, "Revisions and Additions to Caulerpa (Chlorophyta, Caulerpaceae) from the Fiji Islands, South Pacific," Australian Systematic Botany, Vol. 16, No. 4, 2003, pp. 539-548.

[36] C. W. N. Moura and Y. Tomita, Jania ungulata f. brevior (Corallinales, Rhodophyta): Nova Ocorréncia Para o Atlántico," Hidrobiológica, Vol. 8, No. 2, 1998, pp. 145-
153.

[37] J. V. F. Lamouroux, "Exposition Méthodique des Genres de l'ordre des Polypiers: Avec Leur Description et Celle des Principales Espèces," Figurées dans 84 Planches, les 63 Premières Appartenant a l'Histoire Naturelle des Zoophytes d'Ellis et Solander, 1 Folded Table, 84 Plates. Chez Veuve Agasse, Imprimeur-Libraire, Paris, 1821, pp. i-viii, 1-115.

[38] W. H. Harvey, "A Manual of the British Marine Algae: Containing Generic and Specific Descriptions of All the Known British Species of Sea-Weeds, with Plates to Illustrate the Genera," 1849, pp. i-lii, 1-252, 27 pls.

[39] E. Y. Dawson, "Resultados Preliminares de un Reconocimiento de las Algas Marinas de la Costa Pacífica de México," Revista de la Sociedad Mexicana de Historia Natural, Vol. 9, No. 3-4, 1949, pp. 215-255.

[40] I. Pacheco-Ruíz and L. E. Aguilar-Rosas, "Distribución Estacional de Rhodophyta en el Noroeste de Baja California," Ciencias Marinas, Vol. 10, No. 1, 1984, pp. 6780.

[41] L. E. Aguilar-Rosas, "Algas Rojas (Rhodophyta) de la Bahía de Todos Santos, B.C., México," Ciencias Marinas, Vol. 7, No. 1, 1981, pp. 85-101.

[42] L. E. Aguilar-Rosas, E. Baltazar-Valenzuela and I. Pacheco-Ruíz, "Las Algas Marinas Bentónicas de la Rada Portuaria de Ensenada, Baja California," Ciencias Marinas, Vol. 11, No. 3, 1985, pp. 121-126.

[43] L. E. Aguilar-Rosas and I. Pacheco-Ruíz, "Influencia de Desechos Municipales-Industriales Sobre Macroalgas del Norte de Baja California, México," Boletín del Instituto Oceanográfico de la Universidad de Oriente, Venezuela, Vol. 28, No. 1-2, 1989, pp. 77-84.

[44] M. M. Littler and K. E. Arnold, "Primary Productivity of Marine Macroalgal Functional-Form Groups from Southwestern North America," Journal of Phycology, Vol. 18, No. 3, 1982, pp. 307-311. http://dx.doi.org/10.1111/j.1529-8817.1982.tb03188.x

[45] E. Y. Dawson, "Circulation within Bahia Vizcaino, Baja California, and Its Effects on Marine Vegetation," American Journal of Botany, Vol. 39, No. 7, 1952, pp. 425432. http://dx.doi.org/10.2307/2438325

[46] H. W. Johansen, "Coralline Algae. A First Synthesis," Florida, CRC Press, Inc., Boca Raton, 1981, 239 p.

[47] E. K. Ganesan, "Studies on the Morphology and Reproduction of the Articulated Corallines," Journal of Phykos, Vol. 4, 1966, pp. 43-60.

[48] H. W. Johansen and H. B. S. Womersley, "Jania (Corallinales, Rhodophyta) in Southern Australia," Australian Systematic Botany, Vol. 7, 1994, pp. 605-625.

[49] T. Yoshida, "Marine Algae of Japan," Uchida Rokakuho Publishing Co., Ltd., Tokyo, 1998, pp. [1-2], 1-25, 11222.

[50] M. L. Chávez-Barrera, "Una Nueva Especie de Corallinaceae: Jania huertae (Rhodophyta, Florideophycidae)," Ciencia (Mex.), Vol. 27, No. 4-5, 1972, pp. 133-134. 